\title{
Studies in some East Indian Hepaticae. Calobryum Blumei, N. ab E.
}

BY

\section{H. CAMPBELL.}

\section{With Plate I and six Figures in the Text.}

T $\mathrm{N}$ i 830 Nees von Esenbeck described, under the name Monoclea 1 Blumei, a remarkable Liverwort collected by Blume in Java. Later the plant was removed from the genus Monoclea and named Calobryum.

For nearly sixty years no further collections of the plant were made, when it was rediscovered in Java by Goebel. ${ }^{1}$ More recently it has been collected by several botanists in the same location, and is also reported from Sumatra. ${ }^{2}$

In 1906 the writer spent several months in Western Java, and near Tjibodas, on the slope of Mount Gedeh, made several collections of this plant. Material from Mount Salak, near Buitenzorg, where Goebel's specimens were obtained, was also examined.

In addition to the Javanese species, there are two others known at present-C. Mnioides, (Lindb.) St., comes from Japan, and $C$. andinum, (Spruce) St., occurs in some of the West Indies and in South America. The evidently related genus, Haplomitrium, comprising a single species, $H$. Hookeri, is an extremely rare Liverwort found in Great Britain and at a few points on the continent of Europe. These are the only members of the family Calobryaceae, whose relationships with other Hepaticae are very obscure.

Goebel ${ }^{3}$ has given an excellent account of the more important vegetative structures of Calobryum, but details are lacking of the development of the reproductive organs and embryo ; and as the writer's collection afforded very satisfactory material of both male and female plants, as well as a small number of embryos and young sporophytes, it seemed worth while to investigate these somewhat carefully for comparison with the other Hepaticae.

1 Goebel, K. : Morphologische und biologische Studien. Ann. du Jardin Botanique de Buitenzorg, ix, 1891 .

${ }^{2}$ Schiffner, V.: Die Hepaticae der Flora von Buitenzorg, I900.

3 Loc. cit.

[Annals of Botany, Vol. XXXIV. No. CXXXIII. January, 1920.] 
The results of these investigations show that the reproductive structures differ quite as much from those of the typical Liverworts as do the vegetative characters. Our knowledge of the development of the reproductive organs and sporophyte of Haplomitrium are at present too incomplete to make possible a satisfactory comparison with these points in Calobryum. Leitgeb, ${ }^{1}$ as a result of his studies on Haplomitrium, was unable to discover any near relationship with any of the other Hepaticae.

The general aspect of Calobryum (Pl. I, Figs. I-4) is quite different from that of an ordinary Liverwort, since the strongly dorsiventral character, almost universal among Liverworts, is either quite absent, or but slightly developed. The leafy shoot is usually quite upright, and the leaves arranged radially about the axis. There are, however, three rows of leaves

A
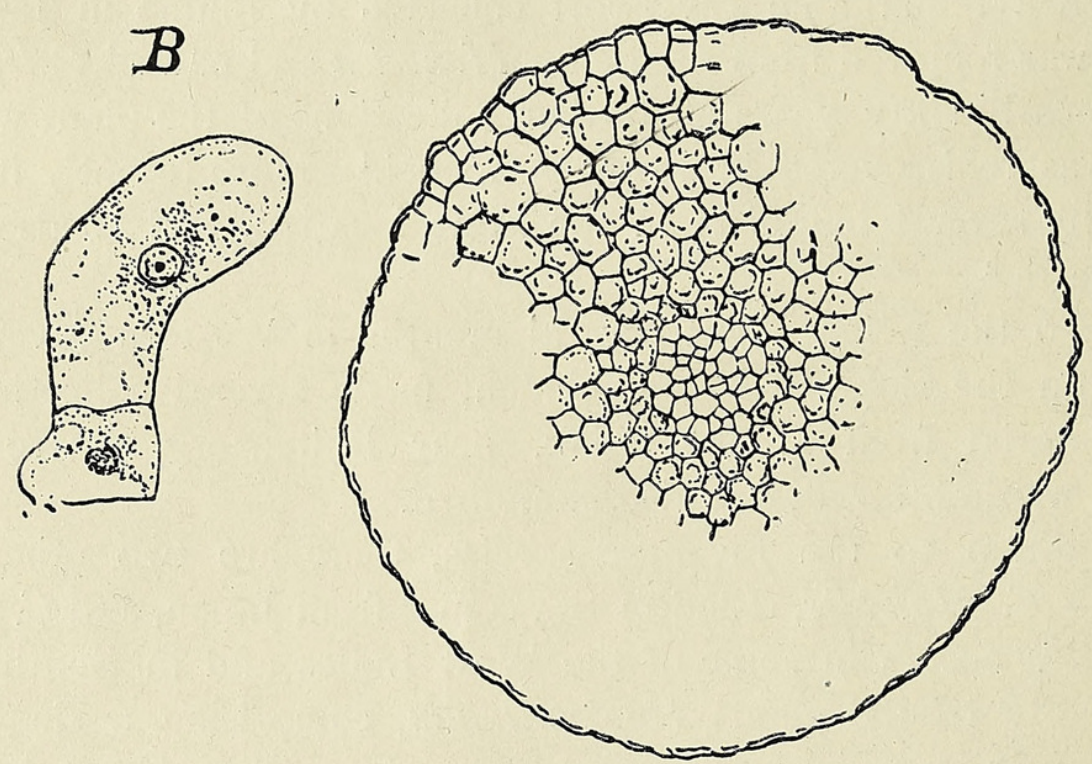

TeXT-FiG. I. A, Cross-section of a leafy shoot of Calobryum ( $\left.\times 5^{6}\right)$; B, a glandular hair $\left(\times 4^{20}\right)$.

as in the ordinary foliose Liverworts, and very often the leaves of one row are smaller than the others and may be compared with the amphigastria or ventral leaves of the familiar leafy genera. Calobryum very much resembles a true moss, such as some of the larger species of Mnium, this resemblance being emphasized, especially in the male plants, by the flattened rosette of large leaves surrounding the terminal disc of antheridia.

The leafy shoots arise from extensively branching prostrate stems forming a sort of rhizome. The branches of the rhizome are cylindrical, and quite destitute of rhizoids, but there may be developed short mucilage-secreting hairs, which also occur upon other portions of the plant. Some of the branches of the rhizome begin to develop leaves near the apex, turn upward to the light, and soon assume the character of leafy

${ }^{1}$ Leitgeb, H. : Untersuchungen über die Lebermoose, ii, 1875. 
shoots (Fig. I, $k$ ). From the bases of these leafy shoots, as well as from the prostrate portions of the rhizome, horizontal leafless branches are formed, which continue the rhizome, which is thus seen to be sympodial in character.

The stem grows from a tetrahedral apical cell, like that of Treubia, or of the foliose Jungermanniales. Goebel figures both longitudinal and transverse sections of the stem apex, and the writer's preparations agree perfectly with Goebel's figures. Haplomitrium, to judge from Leitgeb's account and figures, closely resembles Calobryum in the form of the apical cell. ${ }^{1}$

Seen in cross-section (Text-fig. 2, F), the apical cell appears triangular in outline, one side being somewhat shorter than the other two. Presumably the shorter side is ventral in position. In longitudinal section the lateral faces are strongly curved, and converge above so that the outer free surface of the apical cell is relatively small (Text-fig. 2, A). Goebel's Fig. 25 of the apex of a rhizome branch shows the apical cell to be deeper and narrower than that of the leafy shoot.

Each segment of the apical cell in the upright shoots gives rise to a leaf. The leaves, as Goebel pointed out, differ from those of most Liverworts in being thickened at the base. In this respect Calobryum resembles Treubia, but it is not likely that this indicates any near relationship between the two genera.

The first wall in the young segment divides it into an outer and an inner cell (Text-fig. 2, A). From the outer cell is developed the outer thin portion of the leaf, while the inner cell, by further division, gives rise to the thickened leaf-base and the portion of the stem between it and the next older leaf. The line dividing the apical and basal regions of the young leaf is very clearly defined (Text-fig. 2, A-C).

Sections of the very young leaf parallel with the surface (Textfig. 2, B) show what looks like an apical cell from which a series of basal segments have been cut off. This apical growth, however, is no longer evident in older stages (Fig. C), and the subsequent growth of the leaf is probably due largely to the activity of cells near the base. In the upper part of the leaf the divisions are in two planes only, so that it remains but one cell thick; but in the basal region, where the cells are much larger, divisions may be in all directions, and there is thus formed a thickened basal zone. In the older leaves the thickened basal region merges gradually into the thinner part of the leaf.

The stem, as already stated, consists of two parts, the rhizome-like basal portion and the upright leafy branches. The rhizome, as Goebel pointed out, is sympodial. From the base of the leafy shoots there are produced leafless branches which may themselves give rise to similar ones.

1 Leitgeb : loc. cit. 
Sooner or later the apices of some of these leafless shoots turn upward, develop leaves, and become typical leafy branches upon which are borne the reproductive organs.

Goebel thinks that the leafless branches arise from the apex of the young leafy shoots, but remain dormant until the shoot has elongated,
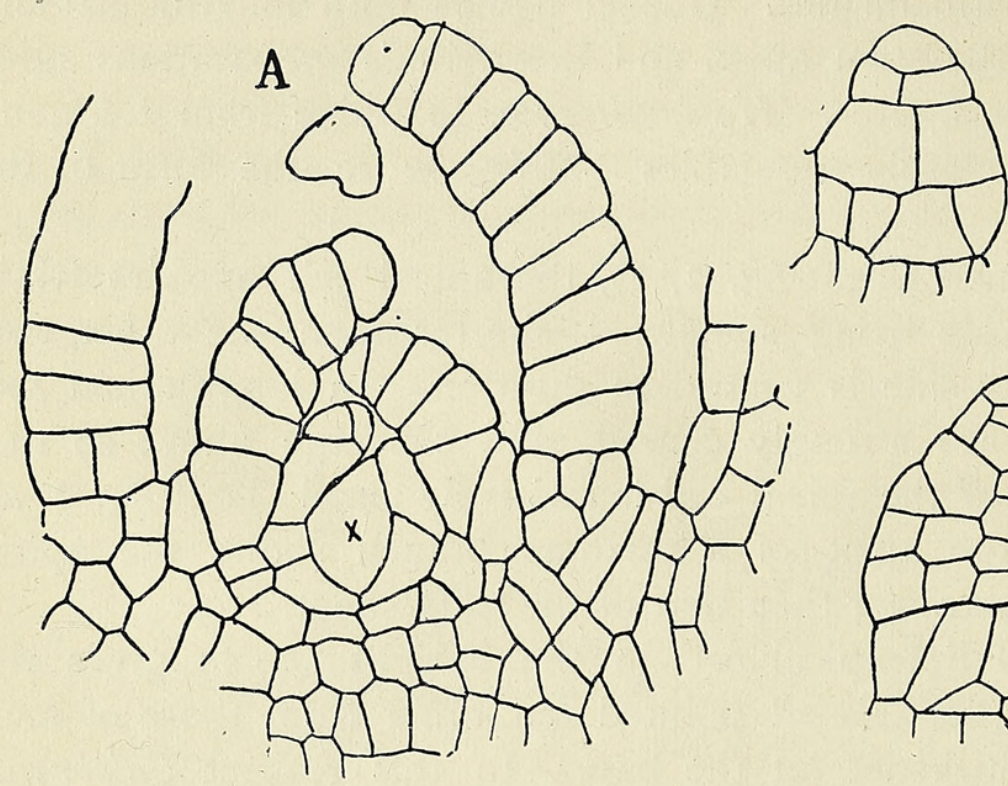

B
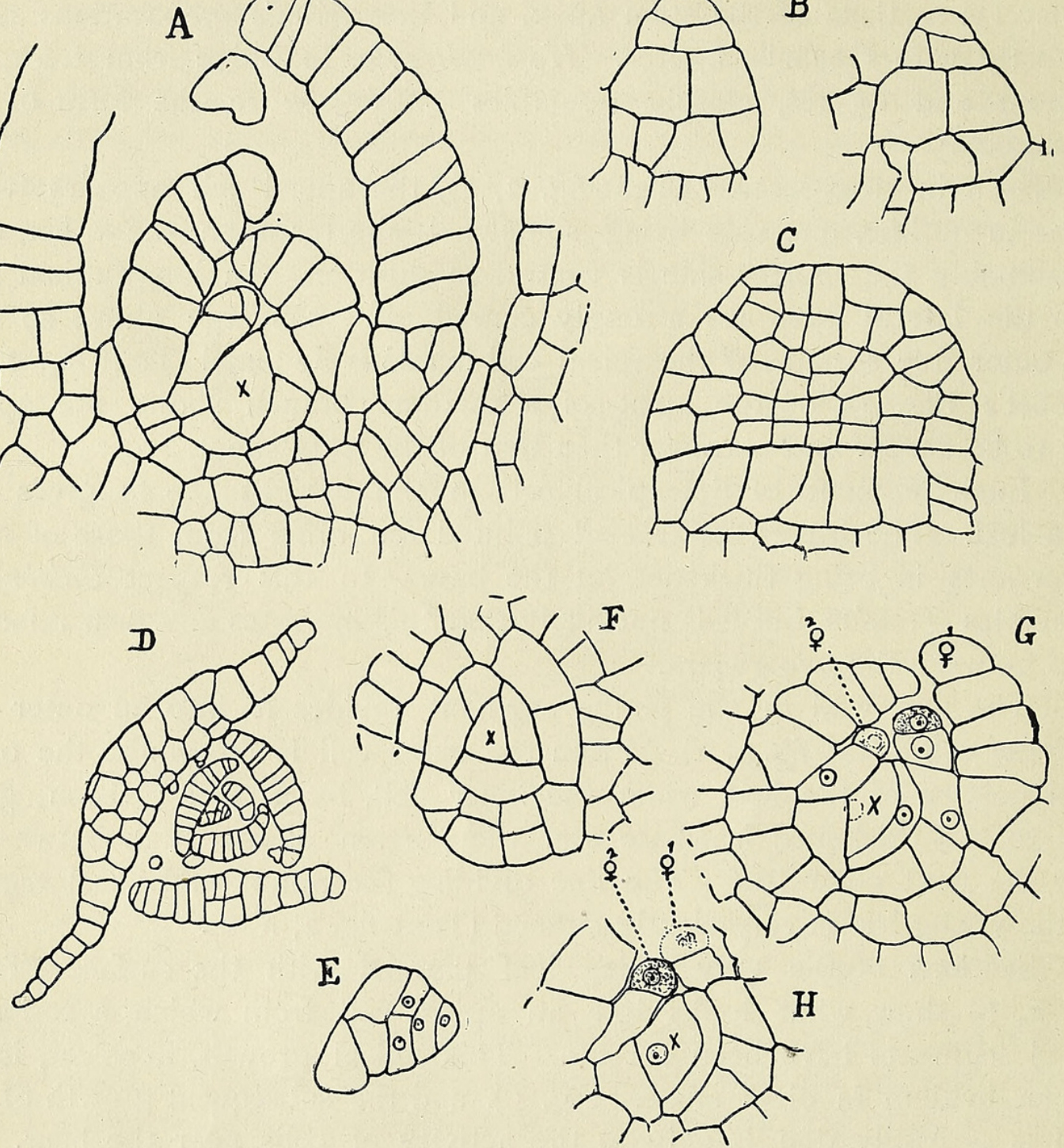

TEXT-FIG. 2. A, Median longitudinal section of the apex of a leafy shoot of Calobryum, showing the apical cell, $x(\times 255)$; B, two sections of a young leaf, cut parallel with the surface $(\times 255)$; c, a similar section of an older leaf; n, transverse section, above the apex, showing the leaf arrangement $\left(\times 6_{5}\right) ; \mathbf{E}$, horizontal section of a young leaf from the same section $(\times 255) ; \mathrm{F}$, apex of the stem in cross-section, showing apical cell, $x ; \mathrm{G}, \mathrm{H}$, two sections of the apex of a branch, showing the first archegonia $\wp^{1}, \wp^{2}(\times 255)$.

so that they seem to be of basal origin. This is contrary to Leitgeb's conclusions for Haplomitrium, where he says there is no terminal branching, and that all the branches are intercalary in origin.

The writer has not made a critical study of this point, but from a somewhat careful examination of a number of much-branched rhizomes he 
is inclined to believe that Leitgeb's interpretation is the correct one (see Fig. I).

A notable character of the stem structure of Calobryum, pointed out by Goebel, is a differentiation of the tissues into an outer region, or cortex, composed of cells containing numerous starch granules, and a conspicuous central cylinder made up of more or less elongated cells, almost destitute of granular contents (Text-fig. I, A). A cross-section of the stem resembles closely that of a typical moss, and it is highly probable that the colourless axial cells have to do with water conduction, as Goebel believes to be the case. So far as the writer is aware, no other foliose Liverwort possesses this moss-like stem-structure.

Numerous short mucilage-secreting hairs occur in almost all parts of the plant. They usually consist of a short base, made up of one or two cells, and a terminal secreting cell, which is elongated, pear-shaped, and with dense granular contents (Text-fig. I, B). Where the stem is perfectly erect, the leaves are inserted horizontally, and one cannot always tell which of the three rows of leaves is the ventral one. In other cases, probably where the shoot is inclined, the leaves are obliquely inserted, and those of one row are decidedly smaller, and may be compared with the amphigastria of the foliose Jungermanniales (Fig. 2). How far this difference in the arrangement of the leaves is due to the influence of ligh remains to be seen, but it is highly probable, as Goebel suggests, that this is the determining factor.

\section{THE REPRODUCTIVE ORGaNS.}

The reproductive organs are formed in considerable numbers at the end of the leafy shoots, and apparently archegonia and antheridia are never formed together. The leaves surrounding the group of reproductive organs are large, and are especially conspicuous in the male 'inflorescence', which, as indicated before, bears a remarkable resemblance to that of such a moss as Mnium.

Within the three large perichaetial leaves surrounding the archegonia there are two or three smaller upright leaves which quite conceal the archegonial group.

The most remarkable feature about the reproductive organs is the extraordinary similarity in the early development of archegonia and antheridium, which for some time are so much alike as to be quite indistinguishable.

Leitgeb ${ }^{7}$ states that in Haplomitrium the early divisions of the antheridium conform to the usual type of the Jungermanniales; but in Calobryum this type is unusual, and in most of the very young antheridia examined the early divisions were exactly like those in the arche- 
gonium. Indeed, were it not for the presence of older stages in the same group, one would without hesitation pronounce the youngest stages to be archegonia. In no case, however, were archegonia and antheridia found together in the older receptacles.

Goebel figures a group of old antheridia, but gives no details of their development.

The young antheridium (Fig. IO) consists of a single basal cell and a hemispherical terminal one which gives rise to the body of the antheri-
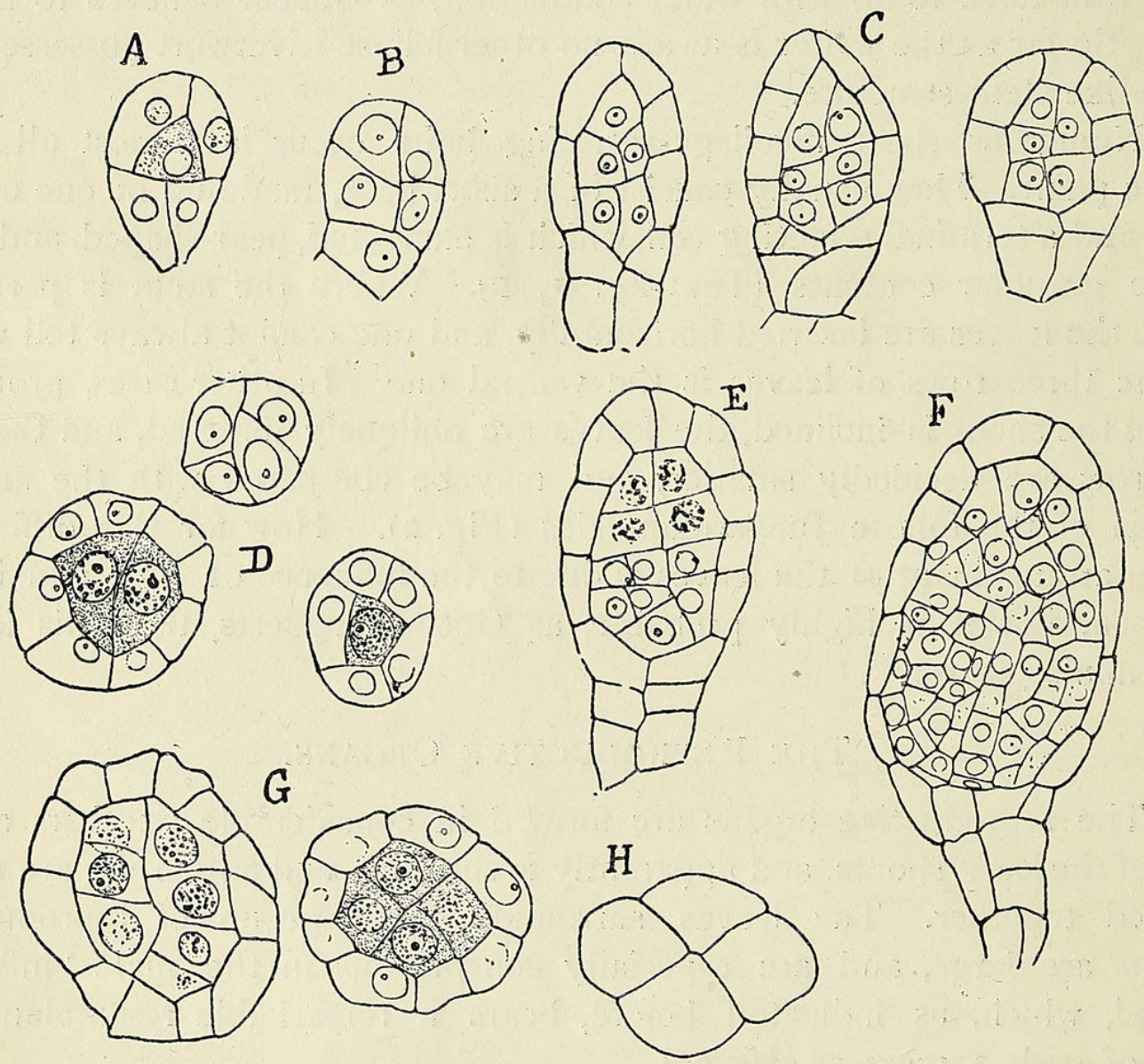

TEXT-FIG. 3. A, B, Two young antheridia $(\times 425)$; B shows a regular octant division; $\mathrm{C}$, three somewhat older antheridia $(\times 280) ; \mathrm{D}$, three young antheridia in cross-section $(\times 425) ; \mathrm{E}, \mathrm{F}$, older antheridia $(\times 280) ; \mathrm{G}$, cross-sections of antheridia $\left(\times 4^{25}\right) ; \mathbf{H}$, cross-section of stalk of mature antheridium $(x 280)$.

dium. The first division wall in the terminal cell is vertical and may be nearly median in position, or it may divide the cell into quite unequal parts (Figs. II, I2). In the former case the next divisions may follow the usual type of the Jungermanniales, i. e. in each half of the antheridium two intersecting walls are formed, which also intersect the median wall, so that a cross-section of the young antheridium shows two triangular inner cells and four peripheral ones. A cross-section of a somewhat older antheridium of this type is shown in Text-fig. 3, D. This type, however, is much less common than that in which the primary wall is at one side 
of the median line, and is intersected by two similar walls, so as to show in cross-section a single triangular cell surrounded by three peripheral ones, exactly as in the young archegonium. These walls may be inclined so as to meet the primary wall, when seen in longitudinal section (Fig. I I), or less frequently they are nearly vertical, and in longitudinal section the axial cell extends to the apex of the antheridium, and later a cap-cell is cut off from it (Figs. 16, I7). The resemblance of these young antheridia to archegonia is quite extraordinary.

A much rarer departure from the type is shown in Text-fig. 3, B. The first divisions were much more like those in the Marchantiales, i. e. there were regular octant divisions before the cutting off of the peripheral cells.

The subsequent development of the antheridium may be briefly summarized. The primary stalk-cell divides by intersecting vertical walls into four, which give rise to the four rows of cells in the stalk of the mature antheridium. The wall of the antheridium consists of a single layer of cells, within which are the numerous sperm cells.

The development of the spermatozoids was followed somewhat in detail, but no notable departure from the type found in other Liverworts was discovered. The nuclei contain eight chromosomes (Fig. I8), and the spermatocytes are not in pairs as is the case in many Hepaticae. The spermatocyte is nearly globular, and surrounded by an evident membrane. The development of the spermatozoid from the contents of the spermatocyte agrees with the accounts given by other investigators for various Hepaticae. As in other cases, the greater part of the body of the spermatozoid is derived from the nucleus, while the cilia arise from the blepharoplast (Fig. 19).

The origin of the first archegonia is exactly the same as in the foliose or 'acrogynous' Jungermanniales (Text-fig. 2, G). Each segment of the apical cell produces a single archegonium, until about half a dozen are produced, when the apical cell is itself transformed into an archegonium, and thus the further growth of the shoot is stopped (Fig. 20). Calobryum is thus truly 'acrogynous', while in the related Haplomitrium the apical cell does not give rise to an archegonium. Many more archegonia are developed, however, but these are all intercalary, and there is no evident relation between them and the earlier formed ones. The number of archegonia may be considerable, but no accurate count was made. Goebel's estimate of 'thirty or more' is probably correct. Archegonia of very different ages occur together, the younger ones arising close to the base of much older ones. .

The early stages of the archegonium, like the antheridium, show remarkable variation. As in other Liverworts, there are first formed three intersecting walls enclosing an axial cell (Fig. 24), but very often these 
three walls converge above, and completely enclose the central cell, exactly as occurs in many of the young antheridia, from which they are hardly to be distinguished (Figs. 22, 25). In such archegonia no cap-cell is formed. Sometimes, however, the three primary walls are vertical, and a cap-cell is cut off from the axial cell in the usual way (Fig. 23); but sometimes this takes place very late. In one observed (Text-fig. 5, G), four canal cells had been formed from the axial cell without a cap-cell having been cut off.

A cross-section of the neck in nearly all cases shows but four peripheral cells, instead of the five or six found in nearly all Hepaticae (Text-fig. 5, B, F 3). This peculiarity is shown by Goebel in his Fig. I $7 a$, but he makes no comment upon it.

The neck canal-cells in the mature archegonium are probably in most
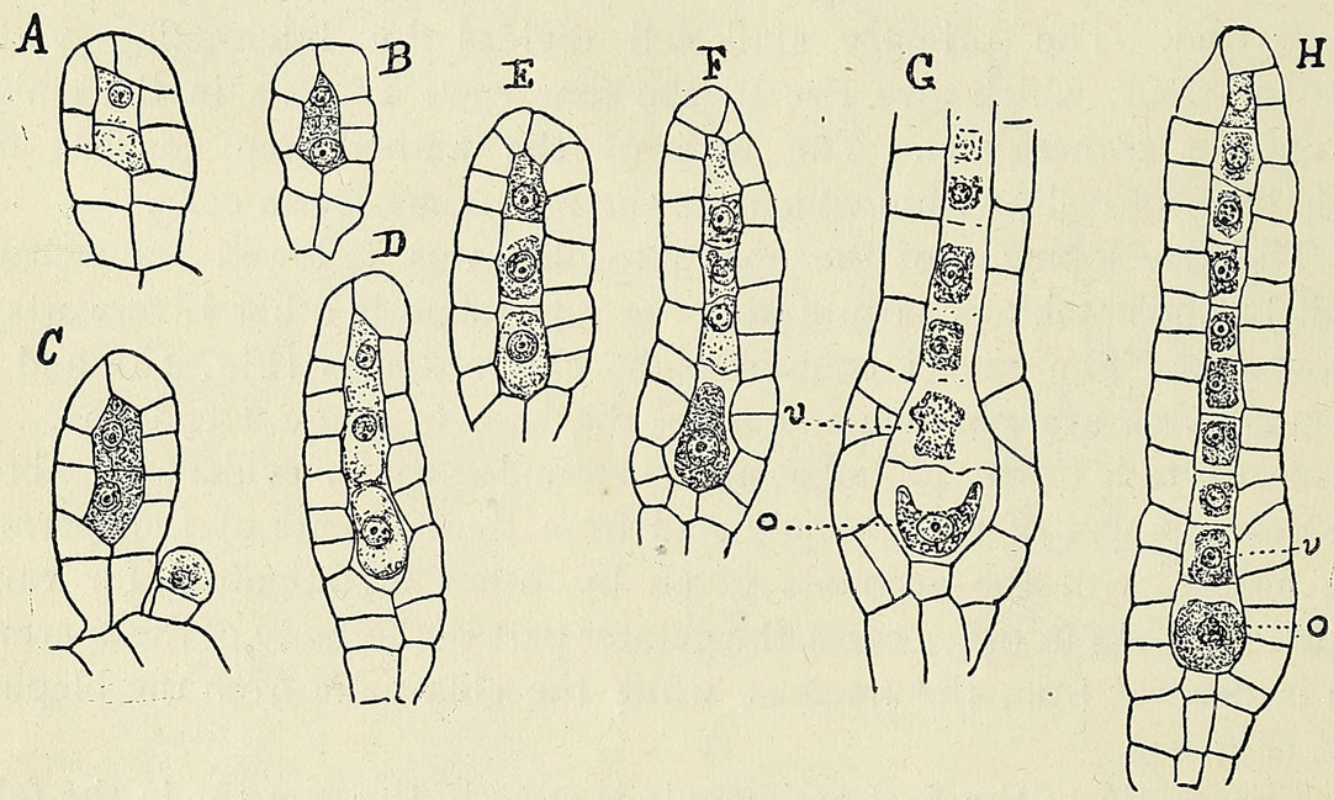

TEXT-FIG. 4. A-H. Development of the archegonium $\left(x_{280}\right)$. C shows a very young archegonium close to an older one. $v$, ventral canal-cell; 0 , the egg.

cases sixteen, but as many as twenty may occur. In one case observed (Text-fig. 5, H) there was a marked enlargement of the apical part of the neck, and the canal-cells in this region had divided so as to suggest the sperm-cells of a young antheridium.

When a cap-cell is present it undergoes the usual quadrant division, and there may be a limited number of secondary divisions in the quadrant cells. In the greater number of cases, however, no proper cap-cell is formed, and the terminal cells of the neck are derived from the original peripheral cells and are not the product of a cap-cell cut off from the axial cell, as is the case in all other Liverworts that have been described. The neck usually shows a more or less marked torsion (Text-fig. 5, A).

The wall of the venter becomes two-layered at maturity. Its central cell becomes elongated, and the tapering upper portion is cut off by 
a definite wall from the lower part, forming the ventral canal-cell. In several cases noted, both the ventral canal-cell and the cell enclosing the egg showed a very conspicuous thickened membrane (Text-fig. $5, \mathrm{D}$ ), which would seem to preclude any possibility of fertilization. In other cases the egg degenerated, and there was some evidence that the ventral canal-cell might be fertilized instead of the egg.

The great similarity in the development of the archegonium and antheridium is of interest in connexion with the question of the homologies
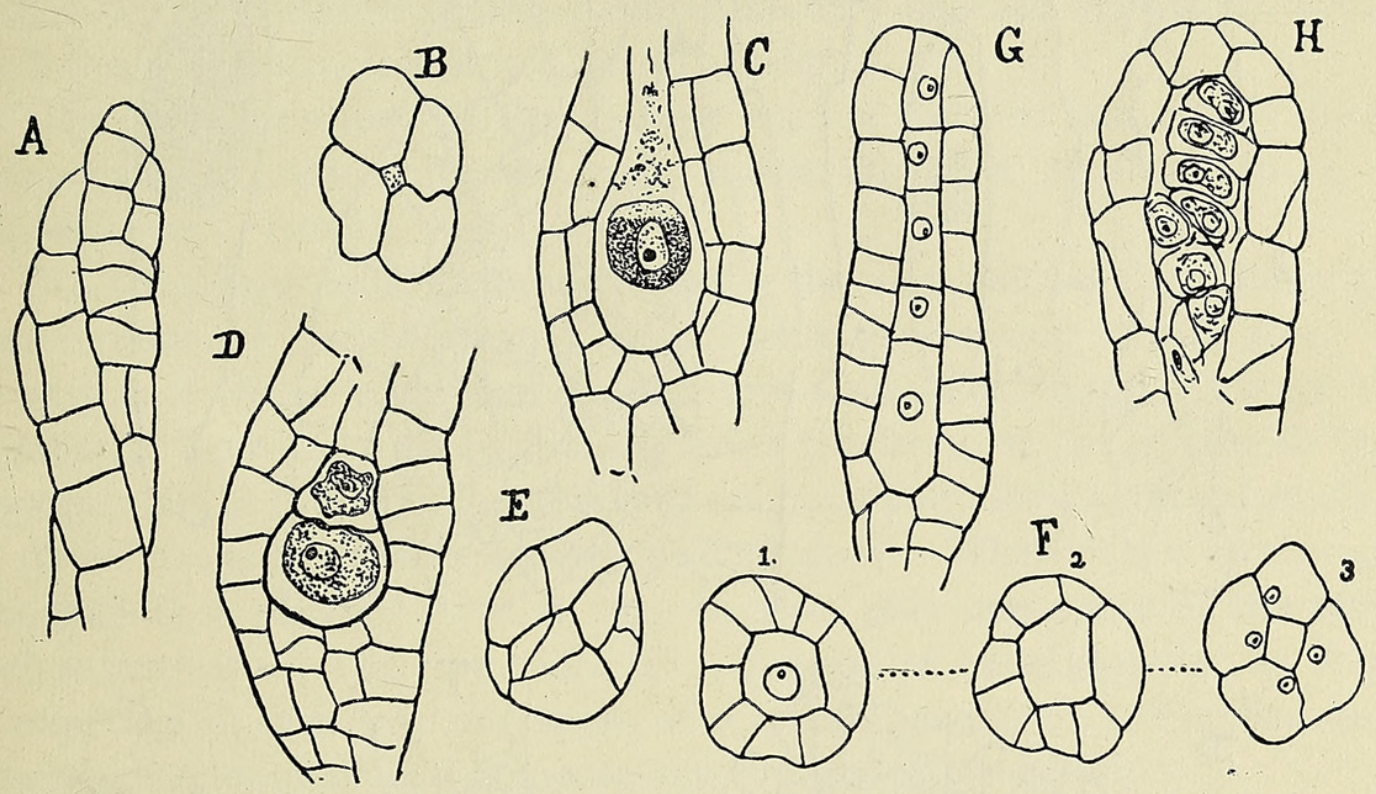

TEXT-FIG. 5. A, Surface view of the neck of an older archegonium, showing the torsion of the neck-cells $(x 280) ; \mathrm{B}$, cross-section of the archegonium neck, showing four peripheral cells $(\times 280)$; $\mathrm{C}$, venter of a ripe archegonium; $\mathrm{D}$, venter of an archegonium in which the ventral canal-cell and the egg-cell are enclosed in a thick membrane; E, apex of the neck, seen from the surface; $F$, three cross-sections of a young archegonium-I, 2, near the base : 3, the neck; G, an archegonium, with four neck canal-cells, in which no cap-cell had been formed; H, apex of an abnormal archegonium, suggesting an antheridium.

of these organs. Goebel ${ }^{1}$ has argued that the two are homologous, and this view would certainly be strengthened by the marked resemblances between the archegonium and antheridium in Calobryum.

\section{THE EMBRyo.}

The material collected by the writer showed only a very few young embryos, so that it was not possible to determine with certainty the succession of divisions in the earlier stages.

The youngest specimen found is shown in Text-fig. 6, A. It corresponds pretty closely with the usual type of the Jungermanniales, i. e. there are apparently two transverse divisions before any longitudinal walls are formed. The basal cell, as is usual in the Jungermanniales, probably takes

1 Goebel, K. : Über Homologien in der Entwickelung männlicher und weiblicher Geschlechtsorgane, Flora, xc. 279-305, 1902. 
no part in the future growth of the embryo. The divisions in the upper segments were decidedly irregular, and it was impossible to judge of the relation of these early divisions to the structures of the older sporophyte.

No stages were found between this very early one and those in which the different regions of the sporophyte were clearly differentiated. The
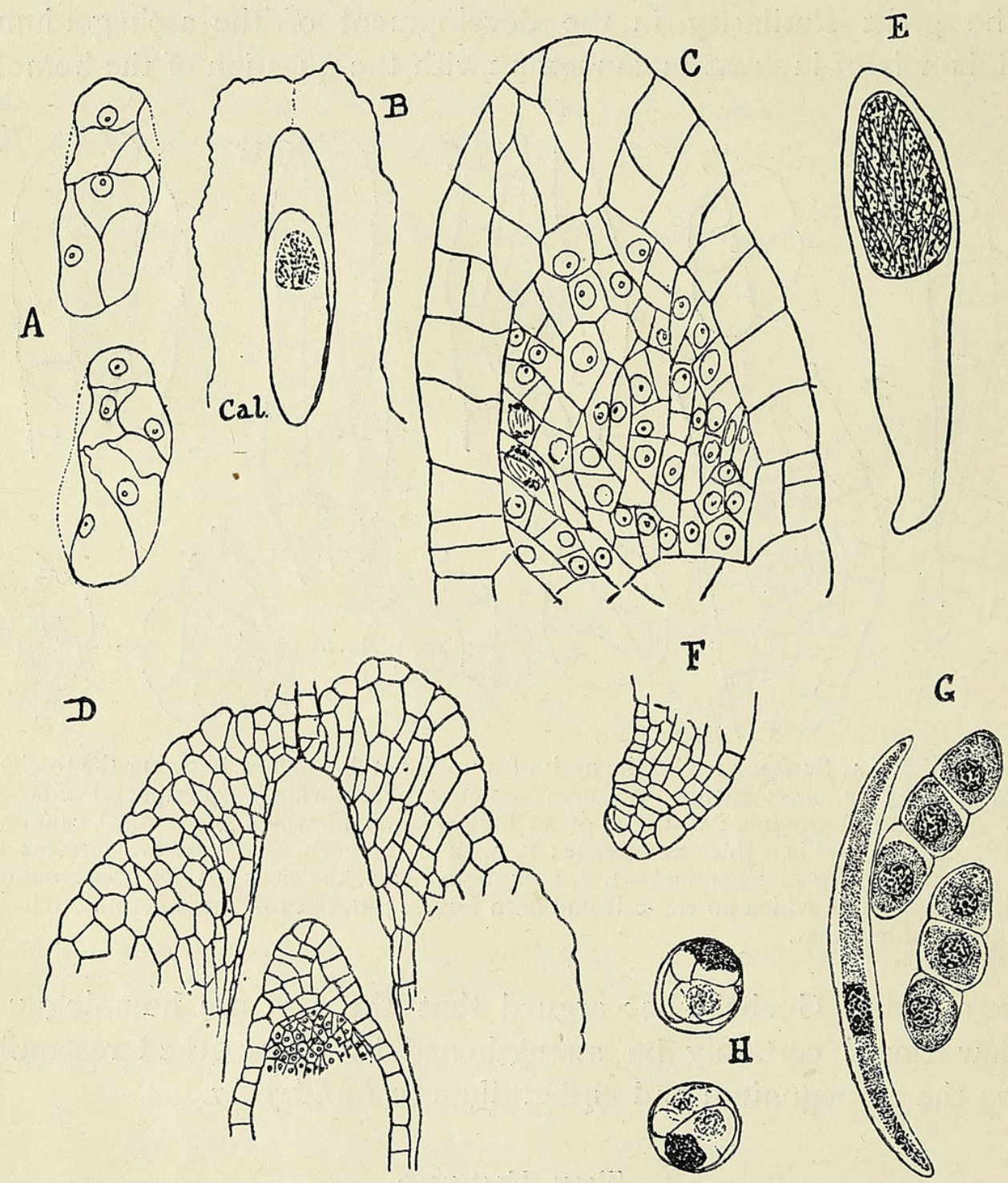

TEXT-FIG. 6. A, Two sections of a young embryo $(\times 280) ; \mathrm{B}$, an older embryo, enclosed in the calyptra, cal. $(\times 38) ; C$, apex of the embryo, shown in $\mathrm{B}(\times 280) ; \mathrm{D}$, upper part of calyptra, and young sporophyte $(\times 66)$; E, longitudinal section of young sporophyte ( $x$ about 30$)$; F, the foot $(\times 66) ; \mathrm{r}$, young spore mother-cells and elater $(\times 425) ; \mathrm{H}$, two young spore-tetrads; only one nucleus in each tetrad is normal.

young sporophyte (Text-fig. $6, \mathrm{E}$ ) is elongated, the basal portion consisting of a pointed foot which merges insensibly into the seta. The capsule is at this stage slightly enlarged and somewhat pointed. The sporogenous tissue is clearly defined, and is bounded by a single layer of wall-cells, in which respect Calobryum resembles the Marchantiales or Sphaerocarpales, rather than the Jungermanniales, where the capsule wall is always composed of 
more than one layer of cells. Of the Marchantiales, probably Monoclea most nearly resembles Calobryum in the elongated form of the capsule as well as the long seta. ${ }^{1}$

As the development proceeds, there is the usual differentiation of the archesporial tissue into the spore mother-cells and elaters; but no definite relation of the two to each other could be detected, nor was any structure recognizable as an elaterophore. The spore mother-cells are often in rows of two to four, lying between the elongated young elaters. Both spore mother-cells and elaters show a definite but very delicate membrane, within which lies the contracted protoplast (Text-fig. 6, G).

The apical portion of the capsule wall is thicker, and finally forms a conspicuous prominence or beak, much like that of Pallavicinia or Podomitrium (Text-fig. 6, D).

No specimens could be found showing the final nuclear divisions of the spore mother-cells, and in nearly all cases the spores were already free. In the only case where the spore tetrads were seen (Text-fig. $6, \mathrm{H}$ ) there had apparently been two successive divisions resulting in the bilateral type of spore ; but of the four young spores only one contained a normal nucleus, the nuclei of the other three having disintegrated. Whether this appearance is normal is a question; but it may be that only one spore of the tetrad reaches maturity. The ripe spore (Fig. 8 ) appears quite globular, as might be expected in case only one spore of a tetrad developed. Further study of spore development will be necessary to decide this question.

The ripe spore has a moderately thick membrane, and the surface is marked by numerous short, blunt prominences. The long, slender elaters have a double spiral (Fig. 7).

A very massive calyptra is develloped, which finally may reach a length of $15 \mathrm{~mm}$., while the seta is two or three times as long, and bears at its tip the slender pointed capsule, about a centimetre in length, and opening by a slit along one side (Figs. 4, 5).

\section{CONCLUSION.}

It is evident that Calobryum and Haplomitrium, although differing in certain particulars, e.g. the position of the archegonia, are closely related, and the establishment of a special family, Calobryaceae, to include these, is entirely warranted. The relationships of the Calobryaceae with the other Hepaticae are very obscure. Goebel regards them as members of a series developed quite independently of the other foliose Hepaticae.

The development of leaves has evidently occurred in several quite independent series among the Liverworts, and the Calobryaceae probably represent the end of such a series, and are not closely related to the foliose

1 Johnson, D. S.: The Development and Relationship of Monoclea. Bot. Gazette, xxxviii. I $85-205$, I 904 . 
Jungermanniales. Whether they are most nearly related to the anacrogynous Jungermanniales, or have been derived from forms more like the Sphaerocarpales, is a question. The character of the sporophyte, with its single layer of wall-cells, would suggest the latter hypothesis.

The establishment of a special family, Calobryaceae, is entirely justified, and perhaps an order, Calobryales, should be established, co-ordinate with the Sphaerocarpales, Marchantiales, and Jungermanniales.

The distribution of the species of Calobryum indicates that the genus was once more generally distributed than at the present time.

\section{EXPLANATION OF PLATE I.}

Illustrating Prof. Campbell's paper on Studies in some East Indian Hepaticae.

Fig. I. Female plant of Calobryum, showing a young leafy shoot, $k$, arising from the shizome. $\times 2$.

Fig. 2. A leafy shoot showing marked dorsiventral habit. $\times 2$.

Fig. 3. A male plant. $\times 2$.

Fig. 4. A shoot with mature sporophyte, $s p$. Natural size.

Fig. 5. An open capsule. $\times 2$.

Fig. 6. A branch upon which two sporophytes have developed; the upper part, with the capsule, has been broken off.

Fig. 7. Part of an elater. $\times 880$.

Fig. 8. Two spores. $\times 880 . a$, in optical section; $b$, surface view.

Fig. 9. Apex of a male plant, with group of antheridia. $\times 100$.

Figs. I0-1\%. Young antheridia seen in median longitudinal section。 $\times 640$.

Fig. 18. Mitosis in young spermatogenic cells, showing eight chromosomes.

Fig. 19. Development of the spermatozoid. $b$, blepharoplast.

Fig. 20. Median section of the apex of a branch in which the apical cell has given rise to an archegonium, $a$; the cell $x$ is the base of the apical cell; $b$, median section of the archegonium.

Figs. 21-23. Young archegonia seen in median longitudinal section. $\times 640$.

Fig. 24. Cross-section of young archegonium. section.

Fig. 25. Three longitudinal sections of a young archegonium. $\times 640, b$ is the median 
Annals of Botany,

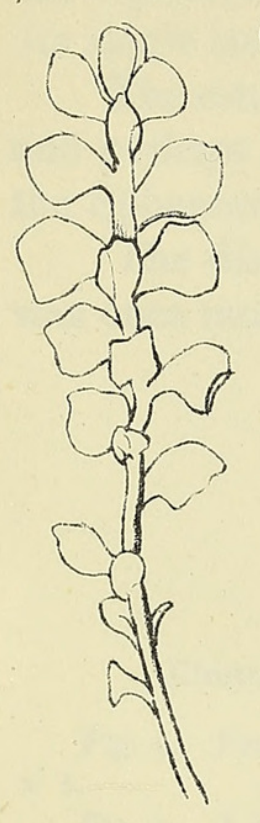

2.
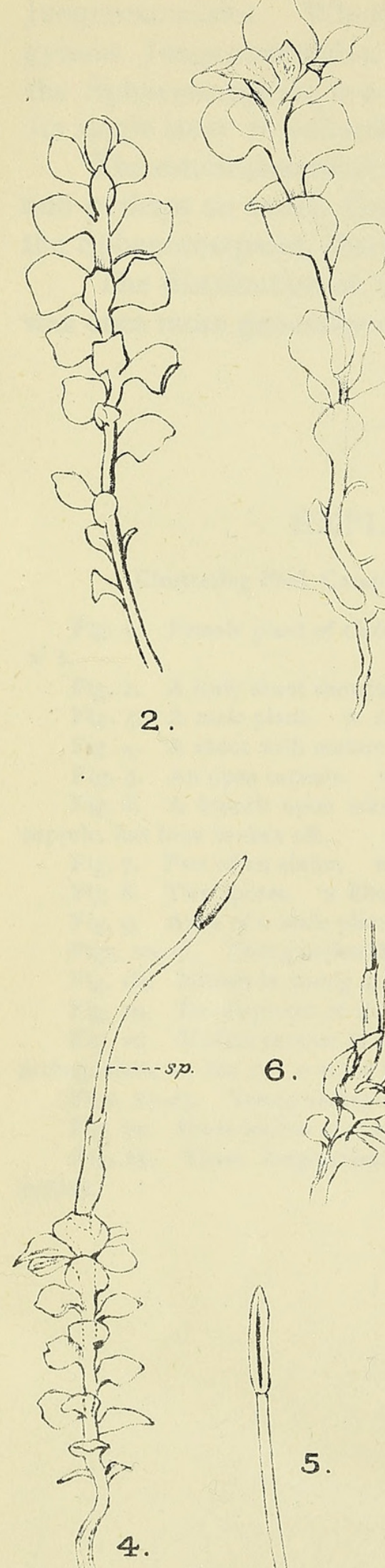

1.

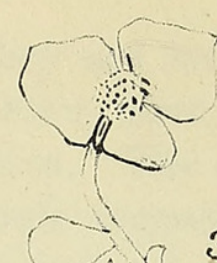

3.
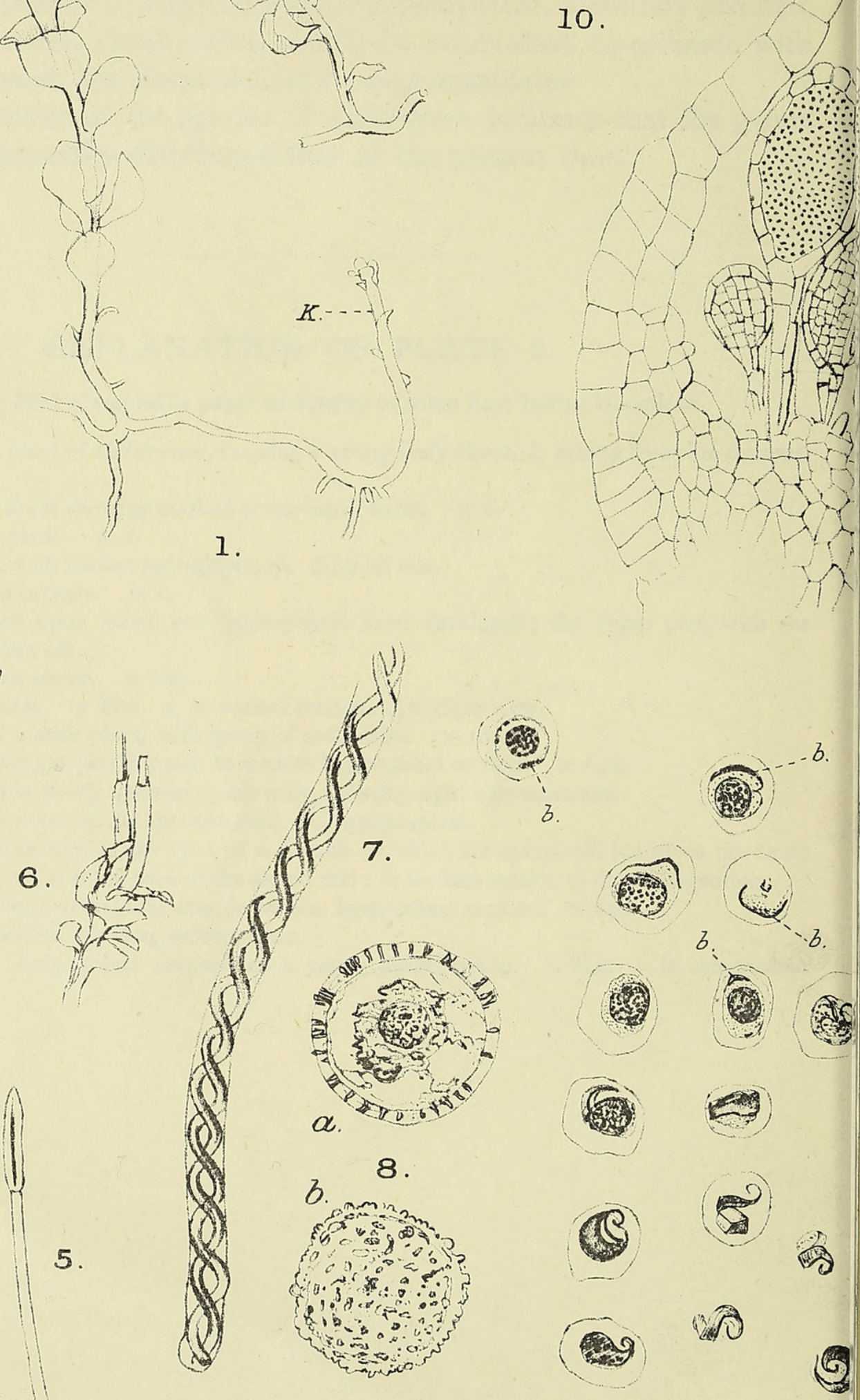

2

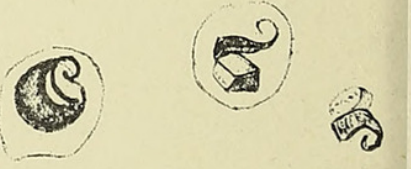

4

(6) 19.

D.H. Cempbell del. 


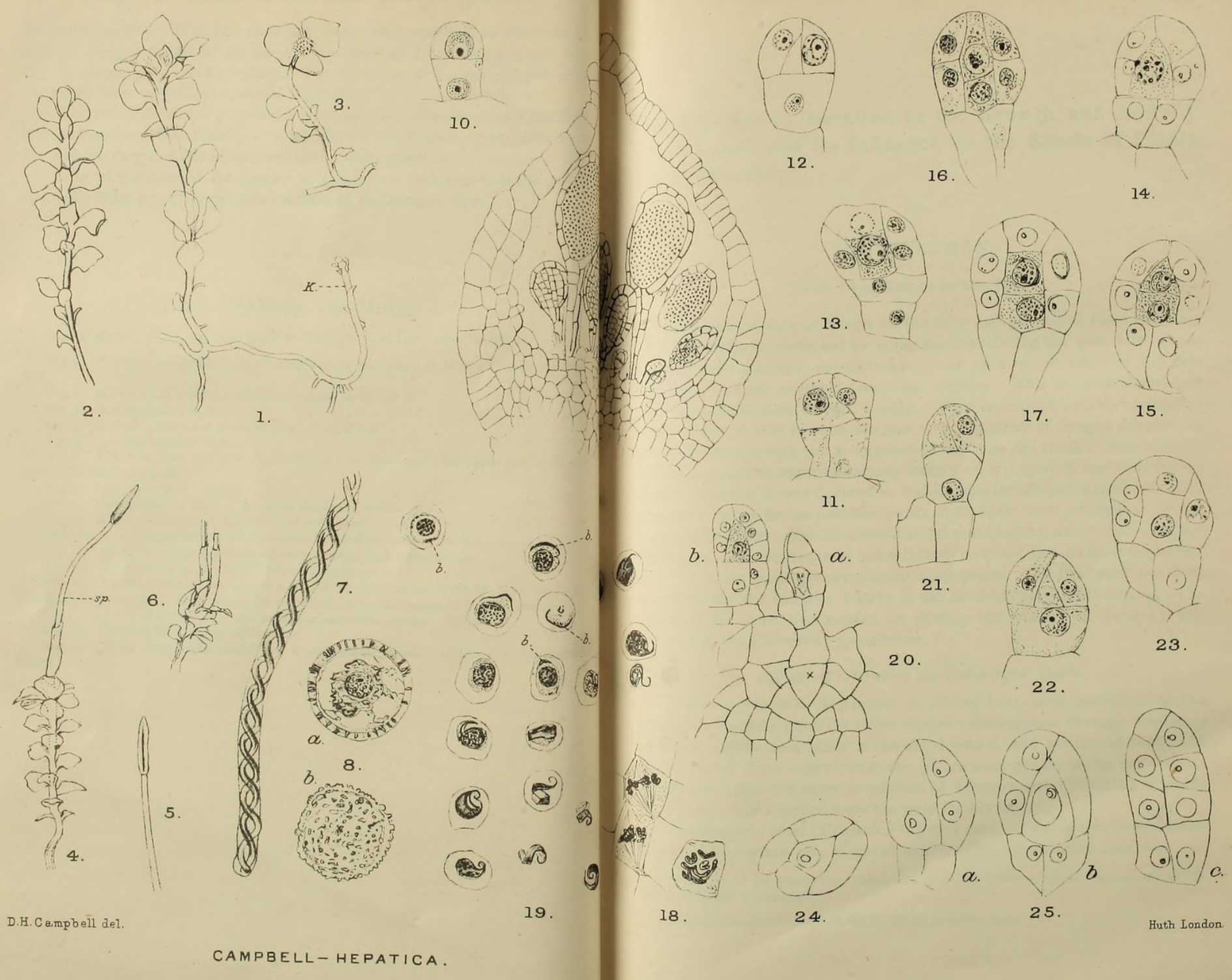




\section{$2 \mathrm{BHL}$ Biodiversity Heritage Library}

Campbell, Douglas Houghton. 1920. "Studies in some East Indian Hepaticae. Calobryum blumei, N. Ab. E." Annals of botany 34, 1-12. https://doi.org/10.1093/aob/os-34.1.1.

View This Item Online: https://www.biodiversitylibrary.org/item/236972

DOI: https://doi.org/10.1093/aob/os-34.1.1

Permalink: https://www.biodiversitylibrary.org/partpdf/320272

\section{Holding Institution}

Smithsonian Libraries

\section{Sponsored by}

Biodiversity Heritage Library

\section{Copyright \& Reuse}

Copyright Status: Not in copyright. The BHL knows of no copyright restrictions on this item.

This document was created from content at the Biodiversity Heritage Library, the world's largest open access digital library for biodiversity literature and archives. Visit BHL at https://www.biodiversitylibrary.org. 